\title{
Yield of castor bean fertilized with sewage sludge and potassium and magnesium sulphate
}

\author{
Thâmara F. M. Cavalcanti ${ }^{1}$, Geraldo R. Zuba Junio ${ }^{1}$, Regynaldo A. Sampaio ${ }^{1}$, \\ João P. Carneiro ${ }^{1}$, Ely S. A. de Oliveira ${ }^{1} \&$ Márcio N. Rodrigues $^{1}$ \\ ${ }^{1}$ Instituto de Ciências Agrárias/Universidade Federal de Minas Gerais. Montes Claros, MG. E-mail: thamara.fmc@gmail.com; juniozuba@yahoo.com.br \\ (Autor correspondente); rsampaio@ufmg.br; jpauloagro@yahoo.com.br; oliveira.sandrinha@yahoo.com.br; marcionrodrigues@gmail.com
}

Key words:

Ricinus communis L.

urban waste

soil fertilization

\begin{abstract}
A B S T R A C T
The aim of this study was to evaluate the yield and nutrition of castor bean in response to fertilization with sewage sludge and potassium $(\mathrm{K})$ and magnesium $(\mathrm{Mg})$ sulphate. The experiment was carried out from January to July 2011. The treatments, in a randomized block design with three replicates, in a Nitosol, corresponded to a factorial scheme $(2 \times 4+1)$ : two doses of $\mathrm{K}$ and $\mathrm{Mg}$ sulphate combined with four doses of sewage sludge $(0,2.60,5.20$ and $10.40 \mathrm{t} \mathrm{ha}^{-1}$, dry basis), applied based on its nitrogen $(\mathrm{N})$ content and the $\mathrm{N}$ requirement for the crop and an additional treatment with NPK. The castor bean grain yield fertilized with sewage sludge did not differ from conventional fertilization, with the maximum value achieved at a dose of $7.5 \mathrm{t} \mathrm{ha}^{-1}$ of sewage sludge. The fertilization with sewage sludge increased zinc and copper levels in the soil to values close to or higher than those in conventional fertilization, without any influence on the concentrations in the leaf. Fertilization with $\mathrm{K}$ and $\mathrm{Mg}$ sulphate increased the levels of these cations in the soil without affecting the concentrations in the leaves. The fertilization with sewage sludge increased the contents of organic matter, sulfur, zinc, iron, copper and boron in the soil, and manganese and boron in castor bean leaves.
\end{abstract}

\section{Palavras-chave:}

Ricinus communis L. resíduos urbanos fertilização do solo

\section{Produção de mamoneira adubada com lodo de esgoto e sulfato duplo de potássio e magnésio}

\section{R E S U M O}

O objetivo deste trabalho foi avaliar a produtividade e nutrição de mamoneira adubada com lodo de esgoto e sulfato duplo de potássio e magnésio. O experimento foi realizado no período de janeiro a julho de 2011. Os tratamentos, no delineamento em blocos casualizados com três repetições, em área de Nitossolo, corresponderam a um fatorial $(1+2 \times 4)$, sendo duas doses de sulfato duplo combinadas com quatro doses de lodo de esgoto, aplicadas com base nos teores de nitrogênio do resíduo e na exigência desse nutriente pela cultura $(0 ; 2,6$; 5,20 e 10,40 $\mathrm{t} \mathrm{ha}^{-1}$, em base seca) e um tratamento adicional com NPK. A produtividade de grãos de mamona adubada com lodo de esgoto não diferiu da adubação convencional sendo o valor máximo atingido com a dose de $7,5 \mathrm{tha}^{-1}$ de lodo de esgoto. A adubação com lodo de esgoto elevou os teores de zinco e cobre no solo a valores próximos ou superiores à adubação convencional, sem nenhuma influência nas concentrações na folha. A adubação com sulfato duplo de potássio e magnésio elevou os teores desses cátions no solo sem influenciar as concentrações na folha. A adubação com lodo de esgoto aumentou os teores no solo de matéria orgânica, enxofre, zinco, ferro, cobre e boro e, na folha de mamoneira, de manganês e boro. 


\section{INTRODUCTION}

The use of sludge in agriculture is one of the most viable forms of disposal for residues, since it allows nutrient cycling, promotes soil physical improvements and is a long-range solution for its destination (Barbosa et al., 2007; Trannin et al., 2008; Chiaradia et al., 2009). However, despite these benefits, the presence of heavy metals, persistent organic substances and pathogenic microorganisms limits its agricultural use (Nascimento et al., 2014a; b).

Agricultural crops fertilized with sewage sludge respond satisfactorily: Lobo et al. (2013) observed increase in grain yield, oil yield, weight of 1,000 seeds and dry matter yield of sunflower with the application of sewage sludge. In addition, Chiba et al. (2008) reported that sewage sludge is an efficient source of nitrogen $(\mathrm{N})$ for sugarcane ratoon and there is no need to complement with $\mathrm{N}$ fertilizers in order to obtain the same yields of stem and sugar of a conventional mineral fertilization. Nogueira et al. (2006) also observed that the yields of intercropped maize and bean did not differ when fertilized with sewage sludge and mineral fertilizer.

Castor bean is a nutrient-demanding species and adequate soil fertilization is essential in order to reach viable yield (Chiaradia et al., 2009). In this context, Nascimento et al. (2011) report that the application of $15 \mathrm{tha}^{-1}$ of sewage sludge is sufficient to substitute mineral fertilization in the yield of grains. Similarly, Chiaradia et al. (2009) observed that the application of $10 \mathrm{t} \mathrm{ha}^{-1}$ of sewage sludge in castor bean cultivation resulted in significant increment of yield and of other biometric characteristics of the plant, with an index of agronomic efficiency of $85 \%$, compared with mineral fertilization.

Potassium (K) remains solubilized in wastewaters during the treatment process in treatment plants; thus, its concentration is always very low in sewage sludge, which requires $\mathrm{K}$ complementation for its agricultural use, depending on the concentration of K in the soil (Martins et al., 2003; Paglia et al., 2007; Garcia et al., 2009).

This study aimed to evaluate the yield and soil and leaf nutrient contents of castor bean, in response to the fertilization with sewage sludge and double sulphate of $\mathrm{K}$ and $\mathrm{Mg}$.

\section{Material AND Methods}

The experiment was carried out using the variety 'BRS Energia' of castor bean (Ricinus communis L.), at the ICA/ UFMG in Montes Claros-MG, Brazil (16 51' 38" S; 44 55'00" W), in an area of Nitosol. Soil chemical and physical characteristics in the layers of 0-20 and 20-40 cm are shown in Table 1.

The experiment was set in a randomized block design, with nine treatments [one additional $+4 \times 2$ factorial scheme] and three replicates. The treatments were:

- Chemical treatment $\left(90 \mathrm{~kg} \mathrm{ha}^{-1}\right.$ of $\mathrm{P}_{2} \mathrm{O}_{5}, 30 \mathrm{~kg} \mathrm{ha}^{-1}$ of $\mathrm{K}_{2} \mathrm{O}$ and $5 \mathrm{~kg} \mathrm{ha}^{-1}$ of $\mathrm{Zn}$ at planting and $40 \mathrm{~kg} \mathrm{ha}^{-1}$ of N, 45 days after plant emergence), applied according to the recommendations for the use of correctives and fertilizers in the state of Minas Gerais (CFSEMG, 1999), using single superphosphate, potassium chloride, urea and zinc sulphate;
Table 1. Chemical and physical characteristics of the soil used in the experiment ${ }^{1}$

\begin{tabular}{|c|c|c|c|c|}
\hline Soil attributes & $\begin{array}{c}\text { Layer (cm) } \\
0-20\end{array}$ & Class $^{2}$ & $\begin{array}{c}\text { Layer }(\mathrm{cm}) \\
20-40\end{array}$ & Class $^{2}$ \\
\hline $\mathrm{pH}$ in water & 6.20 & $\mathrm{H}$ & 6.30 & $\mathrm{H}$ \\
\hline P-Mehlich (mg kg-1) & 3.39 & VL & 1.89 & VL \\
\hline Remaining- $P\left(\mathrm{mg} \mathrm{L}^{-1}\right)$ & 30.79 & - & 21.20 & - \\
\hline $\mathrm{K}\left(\mathrm{mg} \mathrm{dm}^{3}\right)$ & 119.00 & G & 64.00 & M \\
\hline $\mathrm{Ca}\left(\mathrm{cmol}_{\mathrm{c}} \mathrm{dm}^{-3}\right)$ & 6.60 & VG & 5.30 & VG \\
\hline $\mathrm{Mg}\left(\mathrm{cmol}_{\mathrm{c}} \mathrm{dm}^{-3}\right)$ & 1.90 & VG & 1.80 & VG \\
\hline $\mathrm{Al}\left(\mathrm{cmol}_{\mathrm{C}} \mathrm{dm}^{-3}\right)$ & 0.00 & VL & 0.00 & VL \\
\hline $\mathrm{H}+\mathrm{Al}\left(\mathrm{cmol}_{\mathrm{c}} \mathrm{dm}^{-3}\right)$ & 2.01 & $\mathrm{~L}$ & 1.66 & L \\
\hline $\mathrm{SB}\left(\mathrm{cmol}_{\mathrm{c}} \mathrm{dm}^{-3}\right)$ & 8.80 & VG & 7.26 & VG \\
\hline $\mathrm{t}\left(\mathrm{cmol}_{\mathrm{c}} \mathrm{dm}^{-3}\right)$ & 8.80 & VG & 7.26 & G \\
\hline $\mathrm{m}(\%)$ & 0.00 & $\mathrm{VL}$ & 0.00 & $V L$ \\
\hline $\mathrm{T}\left(\mathrm{cmol}_{\mathrm{c}} \mathrm{dm}^{-3}\right)$ & 10.81 & G & 8.93 & G \\
\hline V (\%) & 81.00 & VG & 81.00 & VG \\
\hline Organic matter (dag $\left.\mathrm{kg}^{-1}\right)$ & 5.58 & G & 3.71 & $\mathrm{M}$ \\
\hline Sand $\left(\right.$ dag $\left.\mathrm{kg}^{-1}\right)$ & 44.00 & - & 50.00 & - \\
\hline Silt $\left(\right.$ dag $\left.\mathrm{kg}^{-1}\right)$ & 18.00 & - & 18.00 & - \\
\hline Clay (dag $\left.\mathrm{kg}^{-1}\right)$ & 38.00 & - & 32.00 & - \\
\hline
\end{tabular}

${ }^{1}$ Methodologies described by Tedesco et al. (1995)

${ }^{2}$ Fertility classes according to Alvarez V. et al. (1999); H - High, VH - Very High, VG - Very Good, G - Good, M - Medium, L - Low, VL- Very Low

- Four doses of sewage sludge based on the available $\mathrm{N}$ content $\left(7.62 \mathrm{~kg} \mathrm{t}^{-1}\right)$, calculated according to the methodologies and equations described in the CONAMA Resolution № 375, of August 2006 (Berton \& Nogueira, 2010), defined as follows: Kjeldahl-N $=29.1 \mathrm{~g} \mathrm{~kg}^{-1}$, ammoniacal $\mathrm{N}=2.18 \mathrm{~g} \mathrm{~kg}^{-1}$, Nitrate + Nitrite $=50.6 \mathrm{mg} \mathrm{kg}^{-1}$ and Mineralization Factor $(\mathrm{MF})=$ $20 \%$, with $\mathrm{N}$ extraction and determination in the sewage sludge according to the procedures described in Abreu et al. (2006). The doses were defined as follows: 0, 50, 100 and 200\% of the $\mathrm{N}$ demanded by castor bean $\left(40 \mathrm{~kg} \mathrm{ha}^{-1}\right)$, respectively corresponding to: $0.0,2.60,5.20$ and $10.40 \mathrm{tha}^{-1}$ of sewage sludge, on a dry basis, which was incorporated in the planting furrows.

- Two doses of double sulphate of $\mathrm{K}$ and $\mathrm{Mg}$ : 0 and $150 \mathrm{~kg}$ $\mathrm{ha}^{-1}$, corresponding to 0 and $30 \mathrm{~kg} \mathrm{ha}^{-1}$ of $\mathrm{K}_{2} \mathrm{O}$, applied in the planting furrows.

Fertilization with $90 \mathrm{~kg} \mathrm{ha}^{-1}$ of $\mathrm{P}_{2} \mathrm{O}_{5}$, as single superphosphate, was performed in the treatments receiving sewage sludge and the control (corresponding to the dose 0 of sewage sludge and 0 of double sulphate of $\mathrm{K}$ and $\mathrm{Mg}$ ). The chemical characteristics of the fertilizers are shown in Table 2.

The sewage sludge was obtained from the Sewage Treatment Plant of Montes Claros-MG. The liquid sludge is discarded by an Upflow Anaerobic Sludge Blanket (UASB) reactor, with content of solids of $3 \%$, and is then centrifuged, reaching a concentration of $25 \%$ of solids. Then, it was transported to a Thermal Dryer at $350^{\circ} \mathrm{C}$, for $30 \mathrm{~min}$, and was converted into a sterilized granular material (pellet), or Class A sludge (Table 3 ).

The castor bean crop was planted in $15-\mathrm{cm}$ deep furrows, by placing the seeds $0.6 \mathrm{~m}$ apart between plants and $1 \mathrm{~m}$

Table 2. Nutrient contents in the chemical fertilizers

\begin{tabular}{|c|c|c|c|c|c|c|c|c|}
\hline \multirow{2}{*}{ Fertilizer $^{1}$} & $\mathbf{N}$ & $\mathrm{P}_{2} \mathrm{O}_{5}$ & $\mathrm{~K}_{2} \mathrm{O}$ & $\mathrm{Ca}$ & $\mathrm{Mg}$ & $\mathbf{S}$ & $\mathrm{Zn}$ & $\mathrm{Cu}$ \\
\hline & \multicolumn{6}{|c|}{$\%$} & \multicolumn{2}{|c|}{$\mathrm{mg} \mathrm{kg}^{-1}$} \\
\hline Zinc Sulphate & - & - & - & - & - & 18 & $2 \times 10^{5}$ & - \\
\hline Single Superphosphate & - & 18 & - & 20 & - & 12 & 39.80 & 15.10 \\
\hline Double sulphate of $\mathrm{K}$ and $\mathrm{Mg}$ & - & - & 20 & - & 10 & 22 & 1.91 & 9.52 \\
\hline $\mathrm{KCl}$ & - & - & 58 & - & - & - & - & - \\
\hline Urea & 44 & - & - & - & - & - & - & - \\
\hline
\end{tabular}

${ }^{1}$ Methodologies of extraction and determination described in Brasil (1983) 
Table 3. Chemical characteristics ${ }^{1}$ of the sewage sludge and amounts of nutrients applied with the different doses

\begin{tabular}{|c|c|c|c|c|c|c|c|c|c|c|c|c|c|c|}
\hline \multirow{2}{*}{$\begin{array}{c}\text { Treatment } \\
\text { (t ha-1) }\end{array}$} & \multirow{2}{*}{$\begin{array}{l}\mathrm{pH} \\
\mathrm{H}_{2} \mathrm{O}\end{array}$} & \multirow{2}{*}{$\begin{array}{l}O C \\
(\%)\end{array}$} & \multicolumn{7}{|c|}{ Macronutrients $\left(\mathrm{g} \mathrm{kg}^{-1}\right)$} & \multicolumn{5}{|c|}{ Micronutrients (mg kg-1) } \\
\hline & & & $\mathbf{N}_{\text {total }}$ & $\mathrm{N}_{\text {avail }}$ & $\mathbf{P}$ & $\mathrm{K}$ & $\mathrm{Ca}$ & $\mathrm{Mg}$ & $S$ & $\mathrm{Zn}$ & $\mathrm{Fe}$ & $M n$ & $\mathrm{Cu}$ & B \\
\hline & 5.97 & 10.30 & 29.10 & 7.62 & 7.50 & 33.60 & 23.20 & 2.70 & 19.30 & 625.00 & $44,776.00$ & 195.00 & 147.50 & 8.20 \\
\hline & \multicolumn{14}{|c|}{ Applied amounts $\left(\mathrm{kg} \mathrm{ha}^{-1}\right)$} \\
\hline 2.60 & - & 267.80 & 75.66 & 18.81 & 19.50 & 87.36 & 60.32 & 7.02 & 50.18 & 1.63 & 116.42 & 0.51 & 0.38 & 0.02 \\
\hline 5.20 & - & 535.60 & 151.32 & 39.62 & 39.00 & 174.72 & 120.64 & 14.04 & 100.36 & 3.25 & 232.84 & 1.01 & 0.77 & 0.04 \\
\hline 10.40 & - & 1.071 .20 & 302.64 & 79.25 & 78.00 & 349.44 & 241.28 & 28.08 & 200.72 & 6.50 & 465.67 & 2.03 & 1.53 & 0.09 \\
\hline
\end{tabular}

${ }^{1}$ Methodologies described in Tedesco et al. (1995)

$\mathrm{OC}$ - Organic carbon $\left(\mathrm{g} \mathrm{kg}^{-1}\right)$

$\mathrm{N}_{\text {avail }}$ - content of available nitrogen calculated according to the CONAMA Resolution № 375 (Berton \& Nogueira, 2010)

apart between rows. At 15 days after seeding, thinning was performed, leaving only one plant per hole. Each experimental unit was composed of 24 plants, with 8 evaluated plants, under sprinkler irrigation. At 30 and 60 days after emergence, manual weeding was performed.

Soil sampling was performed in the layer of $0-15 \mathrm{~cm}$, between plants, in the planting furrow, at 30 days after the incorporation of the sewage sludge. Six subsamples were collected, in order to form one single composite sample per plot. Leaf sample was obtained at the beginning of the castor bean flowering stage, by collecting the leaf blade of the forth leaf, counting from the apex, in the eight evaluated plants of each experimental unit.
The obtained data were subjected to analysis of variance and the means of the treatments fertilized with doses of sewage sludge and double sulphate of $\mathrm{K}$ and $\mathrm{Mg}$ were compared with the mean of the treatment with chemical fertilization, at 0.05 probability level by Dunnett test. In addition, the means of the treatments with doses of sewage sludge combined with double sulphate of $\mathrm{K}$ and $\mathrm{Mg}$ were adjusted to regression models, testing the coefficients until 0.10 probability level by $\mathrm{t}$-test.

\section{RESUlts AND Discussion}

The mean values of castor bean grain yield (Table 4 ) revealed that the application of sewage sludge doses providing half the

Table 4. Mean values of castor bean yield and soil attributes, under fertilization with double sulphate of $\mathrm{K}$ and $\mathrm{Mg}$, sewage sludge and NPK

\begin{tabular}{|c|c|c|c|c|c|c|c|}
\hline \multirow{2}{*}{ Variable } & \multirow{2}{*}{$\begin{array}{c}\text { DS } \\
\left(\mathrm{kg} \mathrm{ha}^{-1}\right)\end{array}$} & \multicolumn{4}{|c|}{ Sewage sludge (t ha-1) } & \multirow{2}{*}{ NPK } & \multirow{2}{*}{$\begin{array}{l}\text { CV } \\
(\%)\end{array}$} \\
\hline & & 0 & 2.60 & 5.25 & 10.50 & & \\
\hline \multirow{2}{*}{ Yield $\left(\right.$ t ha $\left.^{-1}\right)$} & 0 & $2.98 \mathrm{~B}$ & $4.05 \mathrm{~A}$ & $4.43 \mathrm{~A}$ & $4.23 \mathrm{~A}$ & \multirow{2}{*}{$4.42 \mathrm{~A}$} & \multirow{2}{*}{11.18} \\
\hline & 30 & $3.62 \mathrm{~A}$ & $3.63 \mathrm{~A}$ & $4.37 \mathrm{~A}$ & $4.25 \mathrm{~A}$ & & \\
\hline \multirow{2}{*}{ OM (dag kg-1) } & 0 & $3.60 \mathrm{~A}$ & $3.40 \mathrm{~A}$ & $3.90 \mathrm{~A}$ & $4.50 \mathrm{~A}$ & \multirow{2}{*}{$3.60 \mathrm{~A}$} & \multirow{2}{*}{11.05} \\
\hline & 30 & $3.20 \mathrm{~A}$ & $3.70 \mathrm{~A}$ & $4.00 \mathrm{~A}$ & $4.60 \mathrm{~B}$ & & \\
\hline \multirow{2}{*}{$\mathrm{pH}-\mathrm{H}_{2} \mathrm{O}$} & 0 & $6.00 \mathrm{~A}$ & $5.50 \mathrm{~B}$ & $5.40 \mathrm{~B}$ & $5.30 \mathrm{~B}$ & \multirow{2}{*}{$6.00 \mathrm{~A}$} & \multirow{2}{*}{3.85} \\
\hline & 30 & $5.90 \mathrm{~A}$ & $5.80 \mathrm{~A}$ & $5.50 \mathrm{~B}$ & $5.70 \mathrm{~A}$ & & \\
\hline \multirow{2}{*}{ P-rem (mg L-1) } & 0 & $44.67 \mathrm{~A}$ & $43.20 \mathrm{~A}$ & $41.83 \mathrm{~A}$ & $44.47 \mathrm{~A}$ & \multirow{2}{*}{$39.13 \mathrm{~A}$} & \multirow{2}{*}{8.53} \\
\hline & 30 & $46.53 \mathrm{~A}$ & $44.47 \mathrm{~A}$ & $45.97 \mathrm{~A}$ & $42.63 \mathrm{~A}$ & & \\
\hline \multirow{2}{*}{$P\left(m g d^{-3}\right)$} & 0 & $110.40 \mathrm{~A}$ & $91.77 \mathrm{~A}$ & $67.23 \mathrm{~A}$ & $103.20 \mathrm{~A}$ & \multirow{2}{*}{$61.67 \mathrm{~A}$} & \multirow{2}{*}{35.08} \\
\hline & 30 & $80.17 \mathrm{~A}$ & $60.53 \mathrm{~A}$ & $67.67 \mathrm{~A}$ & $79.93 \mathrm{~A}$ & & \\
\hline \multirow{2}{*}{$\mathrm{K}\left(\mathrm{mg} \mathrm{dm^{-3 } )}\right.$} & 0 & $119.00 \mathrm{~A}$ & $106.67 \mathrm{~A}$ & $121.67 \mathrm{~A}$ & $98.33 \mathrm{~A}$ & \multirow{2}{*}{$286.67 \mathrm{~A}$} & \multirow{2}{*}{23.30} \\
\hline & 30 & $181.00 \mathrm{~A}$ & $202.67 \mathrm{~A}$ & $188.00 \mathrm{~A}$ & $171.00 \mathrm{~A}$ & & \\
\hline \multirow{2}{*}{$\mathrm{Ca}\left(\mathrm{cmol}_{\mathrm{c}} \mathrm{dm}^{-3}\right)$} & 0 & $10.50 \mathrm{~A}$ & $8.50 \mathrm{~A}$ & $8.50 \mathrm{~A}$ & $10.40 \mathrm{~A}$ & \multirow{2}{*}{$8.30 \mathrm{~A}$} & \multirow{2}{*}{17.75} \\
\hline & 30 & $8.00 \mathrm{~A}$ & $8.20 \mathrm{~A}$ & $8.30 \mathrm{~A}$ & $9.30 \mathrm{~A}$ & & \\
\hline \multirow{2}{*}{$\mathrm{Mg}\left(\mathrm{cmol}_{\mathrm{c}} \mathrm{dm}^{-3}\right)$} & 0 & $1.40 \mathrm{~A}$ & $1.40 \mathrm{~A}$ & $1.40 \mathrm{~A}$ & $1.50 \mathrm{~A}$ & 1374 & \\
\hline & 30 & $1.50 \mathrm{~A}$ & $1.57 \mathrm{~A}$ & $1.47 \mathrm{~A}$ & $1.57 \mathrm{~A}$ & $1.31 \mathrm{~A}$ & 7.41 \\
\hline & 0 & 162.27 A & $147.50 \mathrm{~A}$ & $157.87 \mathrm{~A}$ & $181.13 \mathrm{~A}$ & $12383 \mathrm{~A}$ & 1911 \\
\hline$S\left(\mathrm{mg} \mathrm{am}^{-}\right)$ & 30 & $145.00 \mathrm{~A}$ & $129.60 \mathrm{~A}$ & $145.67 \mathrm{~A}$ & $225.07 \mathrm{~B}$ & $123.83 \mathrm{~A}$ & 19.11 \\
\hline $\mathrm{H}+\mathrm{Al}\left(\mathrm{cmol}_{\mathrm{c}} \mathrm{dm}^{-3}\right)$ & 0 & $2.97 \mathrm{~A}$ & $4.02 \mathrm{~A}$ & $3.63 \mathrm{~A}$ & 4.73 B & $275 \mathrm{~A}$ & 1826 \\
\hline $\mathrm{H}+\mathrm{Al}\left(\mathrm{Cmol}_{\mathrm{c}} \mathrm{am}^{-1}\right)$ & 30 & $2.86 \mathrm{~A}$ & $3.03 \mathrm{~A}$ & $4.18 \mathrm{~B}$ & $3.63 \mathrm{~A}$ & $2.15 \mathrm{~A}$ & 18.20 \\
\hline $\mathrm{SB}\left(\mathrm{cmol}^{\left.-\mathrm{dm}^{-3}\right)}\right.$ & 0 & $12.24 \mathrm{~A}$ & $10.21 \mathrm{~A}$ & $10.21 \mathrm{~A}$ & $12.12 \mathrm{~A}$ & $1040 \mathrm{~A}$ & 1575 \\
\hline $\mathrm{SB}\left(\mathrm{cmol} \mathrm{I}_{\mathrm{c}} \mathrm{am}^{\circ}\right)$ & 30 & $9.93 \mathrm{~A}$ & $10.32 \mathrm{~A}$ & $10.25 \mathrm{~A}$ & $11.30 \mathrm{~A}$ & $10.40 \mathrm{~A}$ & 15.15 \\
\hline & 0 & $15.21 \mathrm{~A}$ & $14.22 \mathrm{~A}$ & $13.84 \mathrm{~A}$ & $16.85 \mathrm{~A}$ & $13.15 \mathrm{~A}$ & 1453 \\
\hline 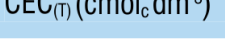 & 30 & $12.79 \mathrm{~A}$ & $13.35 \mathrm{~A}$ & $14.43 \mathrm{~A}$ & $14.93 \mathrm{~A}$ & $13.15 \mathrm{~A}$ & 14.03 \\
\hline$V(\%)$ & 0 & $80.33 \mathrm{~A}$ & $71.67 \mathrm{~B}$ & $73.67 \mathrm{~A}$ & $72.00 \mathrm{~A}$ & 79334 & 465 \\
\hline V(\%) & 30 & $78.00 \mathrm{~A}$ & $77.33 \mathrm{~A}$ & $71.00 \mathrm{~B}$ & $75.67 \mathrm{~A}$ & $19.33 \mathrm{~A}$ & 4.05 \\
\hline & 0 & $2.97 \mathrm{~B}$ & $6.77 \mathrm{~B}$ & $15.13 \mathrm{~B}$ & $38.60 \mathrm{~A}$ & $3100 \mathrm{~A}$ & 4211 \\
\hline $\operatorname{Lin}(\operatorname{mg}$ antro) & 30 & 2.33 B & 6.40 B & $15.93 \mathrm{~A}$ & $35.57 \mathrm{~A}$ & 31.00 A & 42.11 \\
\hline $\mathrm{Fe}\left(\mathrm{ma} \mathrm{dm}^{-3}\right)$ & 0 & 121.47 A & $116.90 \mathrm{~A}$ & $113.60 \mathrm{~A}$ & 154.27 A & $11887 \mathrm{~A}$ & 2501 \\
\hline re (mg amº) & 30 & $121.47 \mathrm{~A}$ & $111.67 \mathrm{~A}$ & $103.80 \mathrm{~A}$ & $164.07 \mathrm{~A}$ & $118.81 \mathrm{~A}$ & 20.01 \\
\hline $\operatorname{Mn}\left(\mathrm{mg} \mathrm{dm}^{-3}\right)$ & 0 & $18.90 \mathrm{~A}$ & $12.30 \mathrm{~A}$ & $15.00 \mathrm{~A}$ & $17.10 \mathrm{~A}$ & $17.20 \mathrm{~A}$ & 26.27 \\
\hline IVIII(III) untr) & 30 & $15.20 \mathrm{~A}$ & $16.20 \mathrm{~A}$ & $18.70 \mathrm{~A}$ & $19.80 \mathrm{~A}$ & & $\angle 0 . \angle 1$ \\
\hline $\mathrm{Cu}\left(\mathrm{mg} \mathrm{dm}^{-3}\right)$ & 0 & $1.37 \mathrm{~A}$ & $1.20 \mathrm{~A}$ & $1.37 \mathrm{~A}$ & $2.03 \mathrm{~B}$ & $0.97 \mathrm{~A}$ & 3022 \\
\hline & 30 & $0.97 \mathrm{~A}$ & $1.10 \mathrm{~A}$ & $1.17 \mathrm{~A}$ & $1.87 \mathrm{~B}$ & $0.91 \mathrm{~A}$ & 30.22 \\
\hline $\mathrm{B}\left(\mathrm{mg} \mathrm{dm} \mathrm{dm}^{-3}\right)$ & 0 & $0.40 \mathrm{~A}$ & $0.40 \mathrm{~A}$ & $0.40 \mathrm{~A}$ & $0.70 \mathrm{~A}$ & $0.50 \mathrm{~A}$ & 36.22 \\
\hline
\end{tabular}

DS - Double sulphate of $\mathrm{K}$ and $\mathrm{Mg}$; Yield - Grains at 13\% humidity

For each variable, means of the treatments with sewage sludge doses and K-Mg sulphate, and those of the NPK treatment, followed by the same letter, do not differ at 0.05 probability level by Dunnett test 
amount of $\mathrm{N}$ demanded by the crop $\left(2.60 \mathrm{t} \mathrm{ha}^{-1}\right)$ or more, or the addition of $30 \mathrm{~kg} \mathrm{ha}^{-1}$ of double sulphate of $\mathrm{K}$ and $\mathrm{Mg}$, promoted grain yields similar to that obtained using NPK fertilization. This fact evidences the potential of sewage sludge to substitute chemical fertilization in the castor bean cultivation. These results corroborate those obtained by Chiaradia et al. (2009), who observed that when sewage sludge is applied in an amount sufficient to provide once or twice the amount of $\mathrm{N}$ demanded by the crop, castor bean yield is higher than that for chemical fertilization. Also, when applied at doses providing half of the recommended $\mathrm{N}$ dose, plant yield corresponded to $93 \%$ of the yield with only mineral fertilization.

Only the highest sewage sludge dose applied together with $\mathrm{K}-\mathrm{Mg}$ sulphate promoted an increase in organic matter superior to NPK fertilization (Table 4). This result agrees with Santos et al. (2009), who observed increase in organic carbon in Quartzarenic Neosol, especially in the humic acid fraction, with the addition of up to $50 \mathrm{Mg} \mathrm{ha}^{-1}$ of sewage sludge. However, Nascimento et al. (2014b), studying different applications of stabilized sewage sludge doses in Haplic Cambisol, did not observe any effect on soil organic matter, probably because the analysis was performed at the end of the cultivation of sunflower.

The application of $\mathrm{K}-\mathrm{Mg}$ sulphate promoted a buffering effect on soil $\mathrm{pH}$, since, in its absence, the application of sewage sludge caused the reduction of this variable (Table 4). This fact was also reflected in the potential acidity $(\mathrm{H}+\mathrm{Al})$ for the highest sewage sludge dose applied without $\mathrm{K}-\mathrm{Mg}$ sulphate; in this case, with the direct influence of the ion hydrogen, since the content of $\mathrm{Al}$ in the soil (exchangeable acidity) was equal to zero. The acidification results from the formation of organic acids and nitrification reactions of the ammoniacal $\mathrm{N}$ present in the sewage sludge or generated in the mineralization of organic N (Boeira, 2006).
As to the nutrients and the other soil fertility indices (Table 4), the content of S for the highest sewage sludge dose combined with K-Mg sulphate was superior to that for NPK fertilization. This fact can be justified considering that both sewage sludge and double sulphate are important sources of S (Table 2), supplying the soil with $293.72 \mathrm{~kg} \mathrm{ha}^{-1}$, for the sum of these sources, and only $64.5 \mathrm{~kg} \mathrm{ha}^{-1}$, for the sum of the contributions from the fertilizers used in the NPK treatment. These results corroborate those obtained by Zuba Junio et al. (2013) for the cultivation of maize, who observed increment in soil S content with the addition of sewage sludge compound.

For $\mathrm{Zn}$ and $\mathrm{Cu}$ (Table 4), only the highest sewage sludge doses promoted contents equal to or higher than those in the NPK treatment, with a Zn supply of at least $6.52 \mathrm{~kg} \mathrm{ha}^{-1}$ for the former and approximately $5.02 \mathrm{~kg} \mathrm{ha}^{-1}$ for the latter. For $\mathrm{Cu}$, the supply was of at least $1.54 \mathrm{~kg} \mathrm{ha}^{-1}$ for the former and zero for the latter.

Despite the differences observed between the fertilizations with sewage sludge and $\mathrm{K}-\mathrm{Mg}$ sulphate and with NPK, regarding $\mathrm{S}, \mathrm{Zn}$ and $\mathrm{Cu}$ in the soil (Table 4), no difference was found for the nutrient contents in castor bean leaves between these treatments (Table 5). However, the lack of differences of the nutrient contents in the leaf tissues seems to be more associated with the dilution, caused by the higher yield of biomass and grains, than with the lack of influence of the fertilizers on the supply of nutrients to plants.

Based on the analysis of variance, there was no interaction between the doses of double sulphate and sewage sludge ( $p>$ 0.05 ); thus, the factors were compared independently (Tables 6 and 7$)$.

Castor bean grain yield and almost all the soil attributes were not influenced by the fertilization with $\mathrm{K}-\mathrm{Mg}$ sulphate, except for $\mathrm{K}$ and $\mathrm{Mg}$, which increased with the application of this fertilizer (Table 6). This occurred because the fertilizer is

Table 5. Mean values of nutrient contents in the plant, in response to the fertilization with sulphate of $\mathrm{K}-\mathrm{Mg}$, sewage sludge and NPK

\begin{tabular}{|c|c|c|c|c|c|c|c|}
\hline \multirow{2}{*}{ Nutrients } & \multirow{2}{*}{$\begin{array}{c}\text { DS } \\
\left(\mathrm{kg} \mathrm{ha}^{-1}\right)\end{array}$} & \multicolumn{4}{|c|}{ Sewage sludge $\left(\mathrm{t} \mathrm{ha}^{-1}\right)$} & \multirow{2}{*}{ NPK } & \multirow{2}{*}{$\begin{array}{l}\text { CV } \\
\text { (\%) }\end{array}$} \\
\hline & & 0 & 2.60 & 5.25 & 10.50 & & \\
\hline \multirow{2}{*}{$N($ dag kg-1) } & 0 & $4.00 \mathrm{~A}$ & $4.08 \mathrm{~A}$ & $4.11 \mathrm{~A}$ & $4.12 \mathrm{~A}$ & \multirow{2}{*}{$4.70 \mathrm{~A}$} & \multirow{2}{*}{9.44} \\
\hline & 30 & $4.35 \mathrm{~A}$ & $3.93 \mathrm{~A}$ & $4.11 \mathrm{~A}$ & $4.22 \mathrm{~A}$ & & \\
\hline \multirow{2}{*}{$P\left(\right.$ dag kg $\left.^{-1}\right)$} & 0 & $0.30 \mathrm{~A}$ & $0.30 \mathrm{~A}$ & $0.30 \mathrm{~A}$ & $0.30 \mathrm{~A}$ & \multirow{2}{*}{$0.30 \mathrm{~A}$} & \multirow{2}{*}{16.23} \\
\hline & 30 & $0.30 \mathrm{~A}$ & $0.30 \mathrm{~A}$ & $0.30 \mathrm{~A}$ & $0.30 \mathrm{~A}$ & & \\
\hline \multirow{2}{*}{$\mathrm{K}\left(\right.$ dag kg $\left.^{-1}\right)$} & 0 & $1.49 \mathrm{~A}$ & $1.45 \mathrm{~A}$ & $1.63 \mathrm{~A}$ & $1.55 \mathrm{~A}$ & \multirow{2}{*}{$1.57 \mathrm{~A}$} & \multirow{2}{*}{13.30} \\
\hline & 30 & $1.59 \mathrm{~A}$ & $1.49 \mathrm{~A}$ & $1.59 \mathrm{~A}$ & $1.68 \mathrm{~A}$ & & \\
\hline \multirow{2}{*}{$\mathrm{Ca}\left(\operatorname{dag~kg}{ }^{-1}\right)$} & 0 & $1.53 \mathrm{~A}$ & $1.64 \mathrm{~A}$ & $1.37 \mathrm{~A}$ & $1.47 \mathrm{~A}$ & \multirow{2}{*}{$1.63 \mathrm{~A}$} & \multirow{2}{*}{12.50} \\
\hline & 30 & $1.76 \mathrm{~A}$ & $1.51 \mathrm{~A}$ & $1.33 \mathrm{~A}$ & $1.52 \mathrm{~A}$ & & \\
\hline \multirow{2}{*}{$M g\left(\right.$ dag kg $\left.^{-1}\right)$} & 0 & $0.25 \mathrm{~A}$ & $0.21 \mathrm{~B}$ & $0.21 \mathrm{~B}$ & $0.25 \mathrm{~A}$ & \multirow{2}{*}{$0.28 \mathrm{~A}$} & \multirow{2}{*}{10.06} \\
\hline & 30 & $0.26 \mathrm{~A}$ & $0.24 \mathrm{~A}$ & $0.21 \mathrm{~B}$ & $0.23 \mathrm{~A}$ & & \\
\hline \multirow{2}{*}{$S\left(\right.$ dag $\left.g^{-1}\right)$} & 0 & $0.37 \mathrm{~A}$ & $0.45 \mathrm{~A}$ & $0.45 \mathrm{~A}$ & $0.38 \mathrm{~A}$ & \multirow{2}{*}{$0.32 \mathrm{~A}$} & \multirow{2}{*}{12.15} \\
\hline & 30 & $0.40 \mathrm{~A}$ & $0.39 \mathrm{~A}$ & $0.40 \mathrm{~A}$ & $0.38 \mathrm{~A}$ & & \\
\hline \multirow{2}{*}{$\mathrm{Zn}\left(\mathrm{mg} \mathrm{kg}^{-1}\right)$} & 0 & $38.67 \mathrm{~A}$ & $39.67 \mathrm{~A}$ & $36.67 \mathrm{~A}$ & $36.00 \mathrm{~A}$ & \multirow{2}{*}{$36.33 \mathrm{~A}$} & \multirow{2}{*}{10.1} \\
\hline & 30 & $33.33 \mathrm{~A}$ & $33.67 \mathrm{~A}$ & $30.00 \mathrm{~A}$ & $34.67 \mathrm{~A}$ & & \\
\hline \multirow{2}{*}{$\mathrm{Fe}\left(\mathrm{mg} \mathrm{kg}^{-1}\right)$} & 0 & $241.00 \mathrm{~A}$ & $196.00 \mathrm{~B}$ & 207.33 B & $229.67 \mathrm{~A}$ & \multirow{2}{*}{$259.00 \mathrm{~A}$} & \multirow{2}{*}{10.00} \\
\hline & 30 & $261.33 \mathrm{~A}$ & $227.67 \mathrm{~A}$ & $268.00 \mathrm{~A}$ & $265.67 \mathrm{~A}$ & & \\
\hline \multirow{2}{*}{$\operatorname{Mn}\left(\mathrm{mg} \mathrm{kg}^{-1}\right)$} & 0 & $47.33 \mathrm{~A}$ & $51.00 \mathrm{~A}$ & $60.00 \mathrm{~A}$ & $71.00 \mathrm{~A}$ & \multirow{2}{*}{$38.00 \mathrm{~A}$} & \multirow{2}{*}{33.9} \\
\hline & 30 & $51.67 \mathrm{~A}$ & $48.67 \mathrm{~A}$ & $40.00 \mathrm{~A}$ & $78.33 \mathrm{~A}$ & & \\
\hline \multirow{2}{*}{$\mathrm{Cu}\left(\mathrm{mg} \mathrm{kg}^{-1}\right)$} & 0 & $8.67 \mathrm{~A}$ & $8.33 \mathrm{~A}$ & $8.33 \mathrm{~A}$ & $8.33 \mathrm{~A}$ & 0234 & 1128 \\
\hline & 30 & $9.33 \mathrm{~A}$ & $8.33 \mathrm{~A}$ & $7.67 \mathrm{~A}$ & $9.00 \mathrm{~A}$ & $9.33 \mathrm{~A}$ & 11.28 \\
\hline $\mathrm{B}\left(\mathrm{mg} \mathrm{kg}^{-1}\right)$ & 0 & $23.57 \mathrm{~A}$ & $25.17 \mathrm{~A}$ & $29.60 \mathrm{~A}$ & $30.70 \mathrm{~A}$ & 20604 & 1058 \\
\hline $\mathrm{B}\left(\mathrm{mg} \mathrm{kg} \mathrm{kg}^{-1}\right)$ & 30 & $25.10 \mathrm{~A}$ & $23.50 \mathrm{~B}$ & $27.33 \mathrm{~A}$ & $27.33 \mathrm{~A}$ & $29.60 \mathrm{~A}$ & 10.58 \\
\hline
\end{tabular}

DS -Double sulphate of $\mathrm{K}$ and $\mathrm{Mg}$

For each variable, means of treatments with sewage sludge doses and K-Mg sulphate, and those of the NPK treatment, followed by the same letter, do not differ at 0.05 probability level by Dunnett test 
Table 6. Mean values of yield, soil chemical attributes and nutrient content in leaves of castor bean fertilized with double sulphate of $\mathrm{K}$ and $\mathrm{Mg}$

\begin{tabular}{|c|c|c|}
\hline \multirow{2}{*}{ Soil atributes } & \multicolumn{2}{|c|}{ DS (kg ha-1) } \\
\hline & 0 & 30 \\
\hline Yield (t ha-1) & $3.93 \mathrm{~A}$ & $3.97 \mathrm{~A}$ \\
\hline OM (dag kg-1) & $3.83 \mathrm{~A}$ & $3.86 \mathrm{~A}$ \\
\hline $\mathrm{pH}-\mathrm{H}_{2} \mathrm{O}$ & $5.56 \mathrm{~A}$ & $5.70 \mathrm{~A}$ \\
\hline P-rem (mg L-1) & $43.50 \mathrm{~A}$ & $44.90 \mathrm{~A}$ \\
\hline$P\left(\mathrm{mg} \mathrm{dm}^{-3}\right)$ & $93.15 \mathrm{~A}$ & $72.08 \mathrm{~A}$ \\
\hline $\mathrm{K}\left(\mathrm{mg} \mathrm{dm}{ }^{-3}\right)$ & $111.42 \mathrm{~B}$ & $185.67 \mathrm{~A}$ \\
\hline $\mathrm{Ca}\left(\mathrm{cmol}_{\mathrm{c}} \mathrm{dm}^{-3}\right)$ & $9.48 \mathrm{~A}$ & $8.45 \mathrm{~A}$ \\
\hline $\mathrm{Mg}\left(\mathrm{cmol}_{\mathrm{c}} \mathrm{dm}^{-3}\right)$ & $1.43 \mathrm{~B}$ & $1.53 \mathrm{~A}$ \\
\hline $\mathrm{S}\left(\mathrm{mg} \mathrm{dm}^{-3}\right)$ & $162.19 \mathrm{~A}$ & $161.33 \mathrm{~A}$ \\
\hline $\mathrm{H}+\mathrm{Al}\left(\mathrm{cmol}_{c} \mathrm{dm}^{-3}\right)$ & $3.84 \mathrm{~A}$ & $3.43 \mathrm{~A}$ \\
\hline $\mathrm{SB}\left(\mathrm{cmol}_{\mathrm{c}} \mathrm{dm}^{-3}\right)$ & $11.19 \mathrm{~A}$ & $10.45 \mathrm{~A}$ \\
\hline $\mathrm{CEC}_{(\mathrm{T})}\left(\mathrm{cmol}_{c} \mathrm{dm}^{-3}\right)$ & $15.03 \mathrm{~A}$ & $13.88 \mathrm{~A}$ \\
\hline$V(\%)$ & $74.4 \mathrm{~A}$ & $75.5 \mathrm{~A}$ \\
\hline $\mathrm{Zn}\left(\mathrm{mg} \mathrm{dm}^{3}\right)$ & $15.87 \mathrm{~A}$ & $15.06 \mathrm{~A}$ \\
\hline $\mathrm{Fe}\left(\mathrm{mg} \mathrm{dm}^{-3}\right)$ & $126.59 \mathrm{~A}$ & $125.25 \mathrm{~A}$ \\
\hline \multicolumn{3}{|l|}{ Plant nutrients } \\
\hline $\mathrm{Mn}\left(\mathrm{mg} \mathrm{dm^{3 } )}\right.$ & $15.80 \mathrm{~A}$ & $17.48 \mathrm{~A}$ \\
\hline $\mathrm{Cu}\left(\mathrm{mg} \mathrm{dm}^{3}\right)$ & $1.49 \mathrm{~A}$ & $1.28 \mathrm{~A}$ \\
\hline $\mathrm{B}\left(\mathrm{mg} \mathrm{dm^{-3 } )}\right.$ & $0.47 \mathrm{~A}$ & $0.43 \mathrm{~A}$ \\
\hline $\mathrm{N}$-plant (dag $\mathrm{kg}^{-1}$ ) & $4.08 \mathrm{~A}$ & $4.14 \mathrm{~A}$ \\
\hline P-plant (dag $\mathrm{kg}^{-1}$ ) & $0.30 \mathrm{~A}$ & $0.30 \mathrm{~A}$ \\
\hline K-plant (dag kg $\left.{ }^{-1}\right)$ & $1.53 \mathrm{~A}$ & $1.59 \mathrm{~A}$ \\
\hline Ca-plant (dag kg-1) & $1.50 \mathrm{~A}$ & $1.53 \mathrm{~A}$ \\
\hline Mg-plant (dag $\mathrm{kg}^{-1}$ ) & $0.23 \mathrm{~A}$ & $0.24 \mathrm{~A}$ \\
\hline S-plant (dag kg-1) & $0.41 \mathrm{~A}$ & $0.39 \mathrm{~A}$ \\
\hline Zn-plant (mg kg-1) & $37.75 \mathrm{~A}$ & $32.92 \mathrm{~B}$ \\
\hline Fe-plant $\left(\mathrm{mg} \mathrm{kg}^{-1}\right)$ & $218.50 \mathrm{~A}$ & $255.67 \mathrm{~B}$ \\
\hline Mn-plant $\left(\mathrm{mg} \mathrm{kg}^{-1}\right)$ & $57.33 \mathrm{~A}$ & $54.67 \mathrm{~A}$ \\
\hline Cu-plant $\left(\mathrm{mg} \mathrm{kg}^{-1}\right)$ & $8.42 \mathrm{~A}$ & $8.58 \mathrm{~A}$ \\
\hline B-plant $\left(\mathrm{mg} \mathrm{kg}^{-1}\right)$ & $27.26 \mathrm{~A}$ & $25.82 \mathrm{~A}$ \\
\hline
\end{tabular}

DS - Double sulphate of $\mathrm{K}$ and $\mathrm{Mg}$; Yield - Grains at $13 \%$ humidity

For each variable, treatment means followed by the same letter do not differ at 0.05 probability level by $\mathrm{F}$ test

an important source of these nutrients (Table 2), supplying the soil with more than $25 \mathrm{~kg} \mathrm{ha}^{-1}$ of $\mathrm{K}$ and $15 \mathrm{~kg} \mathrm{ha}^{-1}$ of $\mathrm{Mg}$. However, the contents of these nutrients in leaf tissues did not increase, as occurred for the Fe content.
For the sewage sludge doses (Table 7), there were increases in the castor bean grain yield, the contents of organic matter, $S$, $\mathrm{Zn}, \mathrm{Fe}, \mathrm{Cu}$ and $\mathrm{Bo}$ in the soil, total CEC and potential acidity $(\mathrm{H}+\mathrm{Al})$, and a reduction of $\mathrm{pH}$ and the percentage of base saturation (V\%).

Araújo et al. (2009) observed that the application of sewage sludge at the dose equivalent to $80 \mathrm{mg} \mathrm{dm}^{-3}$ of $\mathrm{N}$, in the cultivation of Brachiaria decumbens in greenhouse, promoted increase in the contents of organic matter, Fe and $\mathrm{Zn}$ in the soil. Prates et al. (2011) also observed that the application of sewage sludge doses in soil cultivated with Jatropha promoted increase in the content of organic matter and decrease in the percentage of base saturation, while Zuba Junio et al. (2011) verified that the application of sewage sludge compound, in soil cultivated with maize, promoted increase in the contents of $\mathrm{Cu}$ and $\mathrm{Zn}$ in the soil.

The castor bean grain yield reached maximum value $(4.43$ $\mathrm{t} \mathrm{ha}^{-1}$ ) with the sewage sludge dose of $7.46 \mathrm{t} \mathrm{ha}^{-1}$ (Table 7), i.e., with the application of approximately $44 \%$ more than the recommended dose, according to the calculation described in the CONAMA Resolution 375 (Berton \& Nogueira, 2010). Some studies report the application of higher sewage sludge doses for the maximum castor bean yield, such as Nascimento et al. (2011), in Haplic Cambisol, with value of $60 \mathrm{t} \mathrm{ha}^{-1}$. This fact depends on the soil fertility level and the complementation or not of the fertilization with potassium and phosphate fertilizers, since sewage sludge acts effectively as a $\mathrm{N}$ fertilizer. In this context, Chiaradia et al. (2009) observed maximum agronomic efficiency for the sewage sludge dose of $10 \mathrm{t} \mathrm{ha}^{-1}$, in a Red Yellow Argisol cultivated with castor bean.

Soil organic matter increased linearly with the increment in the sewage sludge doses, reaching its maximum value with the maximum dose (Table 7 ). There was a reduction in the magnitude of organic matter, considering the values of before (Table 2) and after (Table 7) the initial cultivation of castor bean. However, the status of this variable in the soil did not change and it remained in the class "Good", according to

Table 7. Regression equations relating castor bean yield and soil chemical attributes with the sewage sludge doses

\begin{tabular}{|c|c|c|c|c|c|}
\hline Variable & Adjustment & $\mathbf{R}^{2}$ & $\begin{array}{l}\text { SSD } \\
\left(\mathrm{t} \mathrm{ha}^{-1}\right)\end{array}$ & SNC & SNC-MY \\
\hline Yield (t ha-1) & $Y=3.26+0.313951 * X-0.021046 * * X^{2}$ & 0.9774 & 7.46 & 4.43 & - \\
\hline $\mathrm{OM}\left(\mathrm{dag} \mathrm{kg}^{-1}\right)$ & $Y=3.33+0.114176^{\star \star \star} X$ & 0.9936 & 10.40 & $4.53 \mathrm{G}$ & $4.18 \mathrm{G}$ \\
\hline $\mathrm{pH}-\mathrm{H}_{2} \mathrm{O}$ & $Y=6.00-0.184091^{* *} X+0.013112^{* *} X^{2}$ & 0.9996 & 0.00 & $6.00 \mathrm{G}$ & $5.36 \mathrm{~L}$ \\
\hline P-rem (mg L-1) & $\mathrm{Y}=\mathrm{Ym}=44.22$ & - & - & - & - \\
\hline$P\left(\mathrm{mg} \mathrm{dm}^{-3}\right)$ & $\mathrm{Y}=\mathrm{Ym}=82.61 \mathrm{MB}$ & - & - & - & - \\
\hline $\mathrm{K}\left(\mathrm{mg} \mathrm{dm} \mathrm{dm}^{-3}\right)$ & $\mathrm{Y}=\mathrm{Ym}=148.54 \mathrm{MB}$ & - & - & - & - \\
\hline $\mathrm{Ca}\left(\mathrm{cmol}_{\mathrm{c}} \mathrm{dm}^{-3}\right)$ & $Y=Y m=8.97 \mathrm{MB}$ & - & - & - & - \\
\hline $\mathrm{Mg}\left(\mathrm{cmol}_{\mathrm{c}} \mathrm{dm}^{-3}\right)$ & $Y=Y m=1.47 B$ & - & - & - & - \\
\hline$S\left(\mathrm{mg} \mathrm{dm}^{-3}\right)$ & $Y=145.34+0.051159 * \star \star \star X^{3}$ & 0.9467 & 10.40 & 202.89 VG & $166.58 \mathrm{VG}$ \\
\hline $\mathrm{H}+\mathrm{Al}\left(\mathrm{cmol}_{c} \mathrm{dm}^{-3}\right)$ & $Y=2.92+0.403191 * * X^{0.5}$ & 0.9908 & 10.40 & $4.22 \mathrm{M}$ & $4.02 \mathrm{M}$ \\
\hline $\mathrm{SB}\left(\mathrm{cmol}_{\mathrm{c}} \mathrm{dm}^{-3}\right)$ & $\mathrm{Y}=\mathrm{Ym}=10.82 \mathrm{MB}$ & - & - & - & - \\
\hline $\mathrm{CEC}_{(\mathrm{T})}\left(\mathrm{CmOl}_{\mathrm{c}} \mathrm{dm}^{-3}\right)$ & $Y=13.88+0.001783^{* * * X^{\beta}}$ & 0.9896 & 10.40 & $15.89 \mathrm{VG}$ & $14.62 \mathrm{G}$ \\
\hline$V(\%)$ & $Y=79.13-2.140525^{\star *} X+0.157007 * X^{2}$ & 0.9990 & 0.00 & $79.13 \mathrm{G}$ & $71.90 \mathrm{G}$ \\
\hline $\mathrm{Zn}\left(\mathrm{mg} \mathrm{dm}^{3}\right)$ & $Y=4.58+0.306602^{\star \star *} \times$ & 0.9842 & 10.40 & $37.74 \mathrm{H}$ & $21.64 \mathrm{H}$ \\
\hline $\mathrm{Fe}\left(\mathrm{mg} \mathrm{dm} \mathrm{m}^{-3}\right)$ & $Y=113.13+0.039818^{\star} X^{3}$ & 0.8896 & 10.40 & $157.92 \mathrm{H}$ & $129.66 \mathrm{H}$ \\
\hline $\operatorname{Mn}\left(\mathrm{mg} \mathrm{dm}^{3}\right)$ & $Y=Y m=16.64 A$ & - & - & - & - \\
\hline $\left.\mathrm{Cu}(\mathrm{mg} \mathrm{dm})^{3}\right)$ & $Y=1.16+0.000704^{* * *} X^{3}$ & 0.9983 & 10.4 & $1.95 \mathrm{H}$ & $1.45 \mathrm{G}$ \\
\hline $\mathrm{B}\left(\mathrm{mg} \mathrm{dm}^{-3}\right)$ & $Y=0.35+0.002677^{* * * X}$ & 0.9333 & 10.4 & $0.64 \mathrm{G}$ & $0.50 \mathrm{M}$ \\
\hline
\end{tabular}

SSD - sewage sludge dose for the maximum value of the variable; SNC - maximum yield or maximum nutrient content in the soil; SNC-MY - soil nutrient content for the application of the sewage sludge dose causing maximum yield (13\% humidity)

Lowercase letters after the values correspond to the fertility classes according to Alvarez V. et al. (1999): H - high, VH - Very good, G - Good, M - Medium, L - Low, VL - Very Low. * ** $\star \star \star$ - significant at $0.05,0.01$ and 0.001 probability level, respectively, by t-test 
Table 8. Regression equations relating nutrient contents in castor bean leaves and the sewage sludge doses

\begin{tabular}{|c|c|c|c|c|c|c|}
\hline Variable & Adjustment & $\mathbf{R}^{2}$ & SSD $\left(\mathrm{t} \mathrm{ha}^{-1}\right)$ & PNC & NCL-MY & $\mathrm{SR}^{1}$ \\
\hline$N\left(\right.$ dag $\left.\mathrm{kg}^{-1}\right)$ & $Y=Y m=4.12$ & - & - & - & - & $4.00-5.00$ \\
\hline$P\left(\right.$ dag $\left.\mathrm{kg}^{-1}\right)$ & $\mathrm{Y}=\mathrm{Ym}=0.30$ & - & - & - & - & $0.30-0.40$ \\
\hline $\mathrm{K}\left(\mathrm{dag} \mathrm{kg}^{-1}\right)$ & $Y=Y m=1.56$ & - & - & - & - & $3.00-4.00$ \\
\hline $\mathrm{Ca}\left(\operatorname{dag} \mathrm{kg}^{-1}\right)$ & $Y=Y m=1.52$ & - & - & - & - & $1.50-2.50$ \\
\hline $\mathrm{Mg}\left(\right.$ dag kg $\left.^{-1}\right)$ & $Y=Y m=0.23$ & - & - & - & - & $0.25-0.35$ \\
\hline$S\left(\operatorname{dag~kg}{ }^{-1}\right)$ & $\mathrm{Y}=\mathrm{Ym}=0.41$ & - & - & - & - & $0.30-0.40$ \\
\hline $\mathrm{Zn}\left(\mathrm{mg} \mathrm{kg}^{-1}\right)$ & $Y=Y m=35.33$ & - & - & - & - & $15.00-40.00$ \\
\hline $\mathrm{Fe}\left(\mathrm{mg} \mathrm{kg}^{-1}\right)$ & $Y=Y m=234.09$ & - & - & - & - & $25.00-100.00$ \\
\hline $\operatorname{Mn}\left(\mathrm{mg} \mathrm{kg}^{-1}\right)$ & $Y=48.64+0.022944 * X^{3}$ & 0.9895 & 10.4 & 74.45 & 58.17 & $20.00-150.00$ \\
\hline $\mathrm{Cu}\left(\mathrm{mg} \mathrm{kg}^{-1}\right)$ & $\mathrm{Y}=\mathrm{Ym}=8.50$ & - & - & - & - & $4.00-10.00$ \\
\hline $\mathrm{B}\left(\mathrm{mg} \mathrm{kg}^{-1}\right)$ & $Y=24.22+0.509341^{\star \star} X$ & 0.7812 & 10.4 & 29.52 & 28.02 & $20.00-30.00$ \\
\hline
\end{tabular}

SSD - sewage sludge dose for the maximum nutrient content in the plant; PNC - maximum nutrient content in the plant

NCL-MY - nutrient content in castor bean leaves for the application of the sewage sludge dose causing maximum yield

${ }^{1}$ Sufficiency range for macronutrients (Martinez et al.,1999) and micronutrients in the leaf (Oliveira, 2004)

*, ** - significant at 0.05 and 0.01 probability level, respectively, by t-test

Alvarez V. et al. (1999). Other studies have reported no change or the reduction of soil organic matter with the application of sewage sludge for plant fertilization (Backes et al., 2009; Nascimento et al., 2014b). However, this reduction can be associated with an increase in biological activity, resulting in intense decomposition of sewage sludge and the organic matter previously existing in the soil, causing the "priming effect", according to Guedes et al. (2006).

Soil $\mathrm{pH}$ decreased with the increase of the sewage sludge doses (Table 7), while potential acidity increased. As reported before, non-limed sewage sludge is known to increase soil acidity, possibly for releasing organic and inorganic acids during the decomposition process (Boeira, 2006).

The percentage of base saturation also decreased with the increase in sewage sludge doses (Table 7). This can be explained by the lack of influence of this residue on the sum of bases and by the increment promoted in the total soil CEC.

The soil nutrients $\mathrm{P}, \mathrm{K}, \mathrm{Ca}, \mathrm{Mg}$ and $\mathrm{Mn}$ were not influenced by the increments in sewage sludge doses (Table 7), although this residue has promoted important supply to the soil, especially of macronutrients (Table 2). However, except for $\mathrm{P}$, which was initially "Very Low" and reached the status of "Very Good", the other attributes remained as "Good" or "Very Good", according to the criteria established by Alvarez V. et al. (1999).

On the other hand, the soil nutrients $\mathrm{S}, \mathrm{Zn}, \mathrm{Cu}$ and Bo increased with the increment of sewage sludge doses (Table 7). Except for Bo, which was classified as "Medium" at the dose causing maximum grain yield, the other mentioned elements remained with statuses from "Good" to "High", which indicates that sewage sludge is a good source of these nutrients.

The contents of nutrients in the plant tissue were not influenced by the sewage sludge doses, except for Mn and Bo (Table 8). As reported before, the lack of response of most nutrients to sewage sludge application seems to be more related to the dilution effect, caused by the increase in leaf biomass and grains, than to an even absorption of nutrients, considering that the supply of most nutrients by the sewage sludge is high (Table 2).

For $\mathrm{Mn}$ and Bo, the increase in the plant contents was approximately linear with the sewage sludge doses (Table 8), although the supply promoted by the residue has not been very pronounced (Table 2). However, only $\mathrm{K}$ and $\mathrm{Mg}$ did not reach adequate nutritional levels for castor bean, which points to the fact that, even with "Good" and "Very Good" availability of these nutrients in the soil, there was no absorption of the required levels. Therefore, it is quite possible that competitive inhibition has occurred, possibly by $\mathrm{Fe}$, whose values were very high in the soil (Table 7) and in the plant (Table 8).

\section{Conclusions}

1. The grain yields of castor bean fertilized with sewage sludge and NPK fertilization did not differ.

2. The application of $7.5 \mathrm{tha}^{-1}$ of sewage sludge promoted the highest grain yield of castor bean.

3. The fertilization with sewage sludge increased the contents of zinc and copper in the soil to values close to or higher than those obtained with NPK fertilization, but with no influence on the contents of these nutrients in castor bean leaves.

4. The fertilization with double sulphate of potassium and magnesium increased the contents of these cations in the soil, but had no influence on their contents in castor bean leaves.

5. The fertilization with sewage sludge increases the contents of organic matter, sulfur, zinc, iron, copper and boron in the soil, and manganese and boron in castor bean leaves.

\section{Acknowledgments}

The authors thank FAPEMIG, CAPES and CNPq, for the financial support to the research.

\section{Literature Cited}

Abreu, M. F. de; Andrade, J. C. de; Falcão, A. de A. Protocolos de análises químicas. In: Abreu, M. F.; Andrade, J. C. de. Análise química de resíduos sólidos para monitoramento e estudos agroambientais. Campinas: IAC, 2006. p.121-158,

Alvarez, V. H.; Novais, R. F.; Barros, N. F.; Cantarutti, R. B.; Lopes, A. S. Interpretação dos resultados das análises de solos. In: Ribeiro, A. C.; Guimarães, P. T. G.; Alvarez, V. H. (org.). Recomendações para o uso de corretivos e fertilizantes em Minas Gerais: $5^{a}$ aproximação. Viçosa: CFSEMG, 1999. cap.5, p.25-32.

Araujo, F. F. de; Gil, F. C.; Tiritan, C. S. Lodo de esgoto na fertilidade do solo, na nutrição de Brachiaria decumbens e na atividade da desidrogenase. Pesquisa Agropecuária Tropical, v.39, p.1-6, 2009. 
Backes, C.; Lima, C. P. de; Fernandes, D. M.; Godoy, L. J. G. de; Kiihl, T. A. M.; Villas Bôas, R. L. Efeito do lodo de esgoto e nitrogênio na nutrição edesenvolvimento inicial da mamoneira. Bioscience Journal, v.25, p.90-98, 2009.

Barbosa, G. M. de C.; Tavares Filho, J.; Brito, O. B.; Fonseca, I. C. B. Efeito residual do lodo de esgoto na produtividade do milho safrinha. Revista Brasileira de Ciência de Solo, v.31, p.601-605, 2007. http://dx.doi.org/10.1590/S0100-06832007000300020

Berton, R. S.; Nogueira, T. A. R. Uso de lodo de esgoto na agricultura. In. Coscione, A. R.; Nogueira, T. A. R.; Pires, A. M. M. (ed.) Uso agrícola de lodo de esgoto: avaliação após a Resolução n 375 do CONAMA. Botucatu: FEPAF, 2010. p.31-50.

Boeira, R. C. Lodo de esgoto como fertilizante em culturas anuais: acidez do solo. Jaguariúna: Embrapa Meio Ambiente, 2006. 3p.

Brasil. Ministério da Agricultura. Análises de corretivos, fertilizantes e inoculantes: Métodos oficiais. Brasília: Laboratório Nacional de Referência Vegetal (LANARV)/ Secretaria Nacional de Defesa Agropecuária, 1983. 104p.

CFSEMG - Comissão de Fertilidade do Solo do Estado de Minas Gerais. Recomendação para uso de corretivos e fertilizantes em Minas Gerais: 5a aproximação. Viçosa: CFSEMG, 1999. 359p.

Chiaradia, J. J.; Chiba, M. K.; Andrade, C. A.; Oliveira, C.; Lavorenti, A. Produtividade e nutrição de mamona cultivada em área de reforma de canavial tratada com lodo de esgoto. Revista Brasileira de Ciência do Solo, v.33. p.701-709, 2009. http://dx.doi. org/10.1590/S0100-06832009000300022

Chiba, M. K.; Mattiazzo, M. E.; Oliveira, F. C. Cultivo de canade-açúcar em Argissolo tratado com lodo de esgoto. I Disponibilidade de nitrogênio no solo e componentes de produção. Revista Brasileira de Ciência de Solo, v.32, p.643-652, 2008. http://dx.doi.org/10.1590/S0100-06832008000200019

Garcia, G. de O.; Gonçalves, I. Z.; Madalão, J. C.; Nazário, A. A.; Bragança, H. N. Características químicas de um solo degradado após aplicação de lodo de esgoto doméstico. Revista Verde de Agroecologia e Desenvolvimento Sustentável, v.4, p.1-12, 2009.

Guedes, M. C.; Andrade, C. A. de; Poggiani, F.; Mattiazzo, M. E. Propriedades químicas do solo e nutrição do eucalipto em função da aplicação de lodo de esgoto. Revista Brasileira de Ciência do Solo, v.30, p.267-280, 2006. http://dx.doi.org/10.1590/S010006832006000200008

Lobo, T. F.; Grassi Filho, H.; Bull, L. T.; Kummer, A. C. B. Efeito do lodo de esgoto e do nitrogênio nos fatores produtivos do girassol. Revista Brasileira de Engenharia Agrícola e Ambiental, v.17, p.504509, 2013. http://dx.doi.org/10.1590/S1415-43662013000500006

Martinez, H. E. P.; Carvalho, J. G. de; Souza, R. B. de. Diagnose foliar. In: Ribeiro, A. C.; Guimarães, P. T. G.; Alvarez, V. H. (org.). Recomendações para o uso de corretivos e fertilizantes em Minas Gerais: 5a aproximação. Viçosa: CFSEMG, 1999. p.143-168,

Martins, A. L. C.; Bataglia, O. C.; Camargo, O. A.; Cantarella, H. Produção de grãos e absorção de $\mathrm{Cu}, \mathrm{Fe}, \mathrm{Mn}$ e Zn pelo milho em solo adubado com lodo de esgoto, com e sem calcário. Revista Brasileira de Ciência do Solo, v.27, p.563-574, 2003. http://dx.doi. org/10.1590/S0100-06832003000300018
Nascimento, A. L.; Sampaio, R. A.; Brandao Junior, D. da S.; Zuba Junio, G. R.; Fernandes, L. A. Crescimento e produtividade de semente de mamona tratada com lodo de esgoto. Revista Caatinga, v.24, p.145-151, 2011.

Nascimento, A. L.; Sampaio, R. A.; Zuba Junio, G. R.; Carneiro, J. P.; Fernandes, L. A.; Rodrigues, M. N. Teores de metais pesados no solo e em girassol adubado com lodo de esgoto. Revista Brasileira de Engenharia Agrícola e Ambiental, v.18, p.294-300, 2014a. http://dx.doi.org/10.1590/S1415-43662014000300008

Nascimento, A. L.; Sampaio, R. A.; Zuba Junio, G. R.; Fernandes, L. A.; Cruz, S. F. da; Carneiro, J. P.; Barbosa, C. F.; Lima, N. N. de. Atributos químicos do solo adubado com lodo de esgoto estabilizado por diferentes processos e cultivado com girassol. Bioscience Journal, v.30, p.146-153, 2014b.

Nogueira, T. A. R.; Sampaio, R. A.; Ferreira, C. S.; Fonseca, I. M. Produtividade de milho e de feijão consorciados adubados com diferentes formas de lodo de esgoto. Revista de Biologia e Ciências da Terra, v.6, p.122-131, 2006.

Oliveira, S. A. Análise foliar. In: Souza, D. M. G.; Lobado, E. (ed.). Cerrado: Correção do solo e adubação. 2.ed. Brasília: Embrapa Informação Tecnológica, 2004. p.245-255.

Paglia, E. C.; Serrat, B. M.; Freire, C. A. de L.; Veiga, A. V.; Borsatto, R. S. Doses de potássio na lixiviação do solo com lodo de esgoto. Revista Brasileira Engenharia Agrícola e Ambiental, v.11, p.94100, 2007. http://dx.doi.org/10.1590/S1415-43662007000100012

Prates, F. B. S.; Sampaio, R. A.; Silva, W. J.; Fernandes, L. A. F; Zuba Junio, G. R.; Saturnino, H. M. S. Crescimento e teores de macronutrientes em pinhão manso adubado com lodo de esgoto e silicato de cálcio e magnésio. Revista Caatinga, v.24, p.101-112, 2011.

Santos, J. A.; Santos, V. B.; Araújo, A. S. F. de. Alterações na atividade microbiana e na matéria orgânica do solo após aplicação de lodo de esgoto. Bioscience Journal, v.25, p.17-23, 2009.

Tedesco, M. J.; Gianello, C.; Bissani, C. A.; Bohnen, H.; Volkweiss, S. J. Análise de solo, plantas e outros materiais. 2.ed. Porto Alegre: UFRGS, 1995. 174p. Boletim Técnico, 5

Trannin, I. C. B., Siqueira, J. O.; Moreira, F. M. S. Atributos químicos e físicos de um solo tratado com biossólido industrial e cultivado com milho. Revista Brasileira de Engenharia Agrícola e Ambiental, v.12, p.223-230, 2008. http://dx.doi.org/10.1590/ S1415-43662008000300001

Zuba Junio, G. R.; Sampaio, R. A.; Nascimento, A. L.; Santos, G. B.; Santos, L. D. T.; Fernandes, L. A. Produtividade de milho adubado com composto de lodo de esgoto e fosfato natural de Gafsa. Revista Brasileira Engenharia Agrícola e Ambiental, v.17, p.706-712, 2013. http://dx.doi.org/10.1590/S1415-43662013000700003

Zuba Junio, G. R.; Sampaio, R. A.; Santos, G. B.; Nascimento, A. L.; Prates, F. B. S.; Fernandes, L. A. Metais pesados em milho fertilizado com fosfato natural e composto de lodo de esgoto. Revista Brasileira de Engenharia Agrícola e Ambiental, v.15, p.1082-1088, 2011. http://dx.doi.org/10.1590/S141543662011001000013 